\title{
Nutritional education in the primary prevention of osteoporosis in perimenopausal and postmenopausal women
}

\author{
Joanna Woźniak-Holecka ${ }^{1}$, Karolina Sobczyk ${ }^{2}$ \\ ${ }^{1}$ Department of Health Care, Silesian Medical College in Katowice \\ ${ }^{2}$ Department of Health Economics and Health Management, Medical University of Silesia in Katowice
}

\begin{abstract}
Osteoporosis affects millions of people in the whole world and brings about far-reaching physical and psychosocial consequences for patients and financial ones for the health care system, and therefore it is classified as one of public health problems and treated as a social disease. Women belong to the increased osteoporosis illness risk group due to lower top bone mass reached earlier in life as compared to men and due to hormonal changes occurring in the menopausal period, which affect loss of the bone mineral density (BMD). Limitation of the osteoporosis-related financial and social costs increase requires efficient preventive actions on the level of early, primary, secondary or tertiary prevention. At all the four osteoporosis prevention phases, the crucial role is played by health education and nutrition education, the latter being the key element of the former one. The nutritional education purpose is to acquaint patients with nutrition recommendations that are the basic element of the osteoporosis prevention and to make them change their nutrition habits, which will improve their osseous metabolism. The education should be based on results of the latest scientific researches and focus on recommendations relating to proper supplementing of calcium and vitamin D, simultaneously including all the other nutrition components, necessary to decrease the osteoporosis risk. The primary prevention oriented to a specific group at risk for osteoporosis, including peri- or postmenopausal women, should be provided in cooperation with the different levels' medical professionals and it should focus on causing positive changes in patients both as regards nutrition habits and physical activities.
\end{abstract}

Key words: osteoporosis, prevention, menopause, nutrition education.

\section{Introduction}

Osteoporosis is an illness defined as a general bone metabolism disease, characterized by a low bone mass, abnormal/impaired osseous tissue micro-architecture, and consequently increased bone fragility and fracture susceptibility. It is defined as a silent epidemic because it causes no symptoms before occurrence of osteoporosis fractures (mainly fractures of the vertebral bodies, proximal femoral bone ends, proximal humeral bone parts or distal forearm bone parts). This illness affects millions of people in the whole world and causes farreaching physical and psycho-social consequences for patients and financial ones for the health care system, and therefore it is classified as one of public health problems and treated as a social disease [1]. The occurrence frequency increases with the age - in women from $2 \%$ at the age of 50 up to $25 \%$ at the age of 80 . According to the estimated data of the National Osteoporosis Foundation (USA), every second woman at the age of $50+$ will experience an osteoporosis fracture, and the risk of such fracture in women is higher than the risk of breast, ovary or uterus body cancers together [2]. Currently, the osteoporosis and osteoporosis fractures treatment costs are estimated in the European Union to be over EUR 36 milliard and it will grow up to over EUR 76 milliard by 2015, and it should be emphasized that such estimations did not include any out-ofhospital treatment or sickness absence costs. The osteoporosis in Europe is a more frequent cause of disability than the neoplasm diseases (excluding the pulmonary carcinoma) [3].

Women belong to the group at the increased risk for osteoporosis due to the lower top bone mass reached earlier in life as compared to men and due to hormonal changes occurring in the menopausal period, which affect a decrease in the bone mineral density (BMD). In peri-menopausal women and for the next 10 years of their post-menopausal period the BMD loss is 2-3\% per year, and then within subsequent years it decreases [1]. The menopause is literally defined as the last menorrhea taking place usually between 45 and 55 year of life in 
a period defined as the peri-menopausal one. The main change occurring in women's organisms on this life stage is a gradual decrease in estrogen production until its total stoppage. These hormonal changes result in a decrease in calcium resorption inside the alimentary tract and increase its urination, which consequently leads to the bone mass decrease. A similar mechanism occurs due to limitation of the dermal vitamin D synthesis, impaired creation of their active metabolites in kidneys or decreasing - after the menopause - the vitamin $D$ receptors in the target organs. Additional factor generating a higher osteoporosis risk in post-menopausal women is discontinuation of the professional activity, which in majority cases turns into significant limitation of any physical activity and results in a decrease of in the kinetic system competence and efficiency [4].

The current demographic changes (ageing of populations) generate higher osteoporosis incidence indexes and increase the number of the osteoporosis-related services rendered by health care institutions. Limitation of the osteoporosis-related financial and social cost growth requires taking efficient preventive actions on early, primary, secondary or tertiary levels. The early prevention means promotion of the habits that foster obtainment of the good quality bones. The primary prevention is aimed at early detection of modifiable illness risk factors and their elimination or reduction (Table I). The secondary prevention aims at the illness diagnosis as early as possible and implementation of proper (pharmacological or non-pharmacological) therapeutic procedures, still before osteoporosis-related fractures occur. The tertiary prevention is aimed at limitation of the osteoporosis effects. For the peri- and post-menopausal women without osteoporosis fractures, primary prevention is applied [5].

At all the four osteoporosis preventive phases, patients education play a very important role. Such education is defined as pro-health education directed to people who use health care; education relating to health conditions, and teaching behaviors connected with the illness

Table I. Most important osteoporosis factors (prepared by the authors on the basis of Kowalczyk-Nowakowska and Dmoch-Gajzierska [6])

\begin{tabular}{ll}
\hline Modifiable factors & Non-modifiable factors \\
\hline - low body mass index & - genetic factors \\
- smoking & - age \\
- alcohol consumption of & - race (white, yellow) \\
3 or more units a day & - late menstruation \\
(unit = 8-10 g of ethanol) & - early menopause \\
- sedentary lifestyle & - secondary amenorrhea \\
- calcium, vitamin D or mag- & - slim silhouette \\
nesium deficit & - diseases causing secondary \\
- excess intake of sodium & osteoporosis \\
- high-protein or high-phos- & - taking some medicines for \\
phate diet & a long time \\
\hline
\end{tabular}

and methods how to maintain the health. The patients education is to help people in taking decisions relating to their own health and to deliver arguments indicating that the development of positive pro-health attitudes and habits is required [7].

Due to a strong connection between the nutrition habits and development of osteoporosis, nutrition education is of special importance as one of the key prohealth education elements. The purpose of nutrition education in the osteoporosis prevention is to acquaint patients with the basic nutrition recommendations and cause changes in their nutrition habits that should improve bone metabolism. Besides the nutrition education it is also necessary to take regular and patient-tailored physical training and avoid possible falls [8]. The efficient nutrition education in osteoporosis patients may be provided as part of primary or special health care, hospital treatment, long-time care services, and also the spa treatment. Moreover, this process may be realized out of institutions (education in the family or by mass-media).

\section{Nutrition recommendations and diet supplements in osteoporosis}

The osteoporosis diet-prevention requires, first of all, maintaining the proper organism nutrition status, which is possible thanks to consumption of 4-5 meals everyday at regular time intervals, balanced in both acid-forming and base-forming elements. The acid-forming elements are slaughter animals, venison, poultry or fish and their products as well as eggs and cereals. The base-forming ones include milk, milk products, vegetables and fruits. It is especially important in the osteoporosis nutrition practice to include in each consumed meal base-forming products that make it possible to keep a proper level of mineral components in the organism, including calcium [9].

The menu, especially for post-menopausal women, should be planned according to the nutrition pyramid for elderly people, where water is the basis [10]. According to Polish nutrition standards for women, the amount of water delivered to their organisms should be $2700 \mathrm{ml}$ a day. Attention should also be paid to a greater dehydration risk in elderly people, resulting from hypodipsia, limited water availability, limited kidney efficiency and also due to an increase in water volume secreted through the skin. In order to hydrate the organism properly it is recommended, first of all, to drink noncarbonated water. Drinking of carbonated water should be limited (the carbon dioxide initiates thirst inhibition in the stomach, and this make it difficult to supplement the water loss) similarly as the carbonated, sweetened and colored drinks (orthophosphoric acid negatively affects calcium and magnesium assimilation) [11].

Proper nutrition in osteoporosis prevention requires everyday intake of cereal products as the basic energy source, and fruits and vegetables as the valuable source 
of vitamins and mineral salts. The carbohydrates should provide $55-60 \%$ of the daily calorific requirement, including maximum $10 \%$ of monosaccharides. Simultaneously it should be kept in mind that carbohydrate deficit in a diet causes production of ketone compounds, resulting from a difficult breakdown of acetyl-CoA, and acidification of the organism fosters osteoporosis [12].

Moreover, in order to ensure proper calcium supply, it is necessary to consume 2-3 milk product portions. Intake of the necessary protein volume requires also, beside consuming of 2-3 milk products, introducing in the daily menu fish or poultry meals as well as leguminous plants and nuts. The proteins should be $12-15 \%$ of the daily energy demand, including minimum $50 \%$ of full-value proteins, which in elderly people results from possible digestion or absorption problems. The meal additions should be plant oils consumed in moderate amounts (25-30\% of the daily calorific demand). It is extremely important to deliver to organism, in everyday diet, unsaturated fatty acids with simultaneous limitation of the saturated ones that make calcium absorption difficult $[10,13]$. Table II shows the basic sources of carbohydrates, proteins or fats in a diet.

Despite the fact that in the osteoporosis there are strong genetic predispositions (80\%), the calcium intake level, besides the physical activity, is deemed to be the most important modifiable osteoporosis risk factor. It is estimated that almost $10 \%$ of osteoporosis-related fractures may be attributed to a low calcium intake (in the case of the physical activity it is $23 \%$ ) [1]. The periand post-menopausal women are specially exposed to a calcium deficit due to the above mentioned changes occurring in their organisms. The recommended calcium intake by women within the discussed life period is $1500 \mathrm{mg}$ a day. Proper intake of this element in a diet has a crucial significance for maintenance of the mineral bone density, and therefore it is the key factor in both osteoporosis prevention and therapy [8]. According to Peters et al., the high calcium intake may decrease

Table II. Sources of the basic nutrition components (prepared by the authors on the basis of Wieczorek-Chełmińska [14])

\begin{tabular}{ll}
\hline Nutrition component & Sources \\
\hline $\begin{array}{l}\text { complex carbohy- } \\
\text { drates }\end{array}$ & $\begin{array}{l}\text { cereals (bread, groats, pasta), pota- } \\
\text { toes, leguminous plants, root vegeta- } \\
\text { bles, tuber vegetables }\end{array}$ \\
\hline monosaccharides & $\begin{array}{l}\text { fruits, vegetables, milk products, re- } \\
\text { fined sugar, confectionery, sweets }\end{array}$ \\
\hline animal protein & $\begin{array}{l}\text { eggs, milk and milk products, meat, } \\
\text { poultry, fishes }\end{array}$ \\
\hline plant protein & leguminous plants, nuts \\
\hline saturated fats & $\begin{array}{l}\text { butter, pork fat, cream, meat and meat } \\
\text { products, full-fat milk and full-fat dairy } \\
\text { products, confectionery, sweets }\end{array}$ \\
\hline unsaturated fats & $\begin{array}{l}\text { plant oils, fishes and sea mammals, } \\
\text { egg yolk, soya seeds, nuts }\end{array}$ \\
\hline
\end{tabular}

the osteoporosis fracture risk as much as by $60 \%$, due to the fact that it plays an important role in decrease in the bone remodeling and decrease in the age-related bone mass loss [15]. The connection of the low calcium intake and occurrence of osteoporosis and osteoporosisrelated fractures is documented also by Waresnsjo et al. basing on the 19-year investigation (1987-2006) of over 61,000 Swedish women born in 1914-1948. According to the authors, almost $10 \%$ of the femoral neck bone fractures may result from the low calcium intake, while the hip fracture risk drops by $3.34 \%$ as related to each calcium intake growth by $300 \mathrm{mg}$ [16]. Similar research on a smaller cohort (707 post-menopausal women) was carried out by Rouzi et al., who came to a conclusion that as much as $26.4 \%$ of osteoporosis fractures should be attributed to the low calcium intake, and even a small growth of its intake (by $120-150 \mathrm{mg}$ ) may play a significant role in the osteoporosis fractures prevention [17]. Similar results were shown by Key et al. basing on the prospective research of nearly 35,000 British people, where they show that the fracture risk in $50+$ women is larger with the daily calcium intake below $700 \mathrm{mg}$ as compared to the intake of $1200 \mathrm{mg}$ minimum [18]. Also Tang et al. proved in their research that intake of the optimal calcium quantity (800-1000 mg a day) by the $50+$ people results in a decreased bone fracture risk, and such effect depends on the dose - a larger calcium intake (ca. $1200 \mathrm{mg}$ ) decreases the fracture risk to a higher degree [19].

Calcium supplementation should be introduced in justified cases only (high-risk group, impossible obtainment of enough calcium from a diet), because the researches show that such actions cause side effects. These are mainly mild gastric and intestinal disorders, but amongst the 80+ women there is also an increased cardiac and vascular risk connected with this supplementation [15]. An increased heart and vascular incidents risk, connected with the calcium preparations supplementation, is confirmed by Bolland et al. in their meta-analysis. The myocardial infarction risk increases up to $27-31 \%$. Therefore, before administration of this therapeutic supplementation procedure in elderly people, it is necessary to analyze carefully all the possible involved losses and advantages [20]. Usually the 500$1000 \mathrm{mg}$ calcium supplementation is applied, according to individual indications. In order to increase possible calcium resorption and minimize side effects, the daily dose should be divided to two smaller portions and consumed with meals (calcium carbonate, calcium phosphate) or in fasting state (calcium citrate), and the supplementation cannot be applied simultaneously with the iron supplementation or treatment by means of bisphosphonates or tetracycline [21].

Proper calcium intake may be provided in the balanced diet, rich in milk and milk products, which are the most available calcium source in food. Besides the proper cal- 
cium intake, it is also significantly important to limit nutrition factors decreasing its absorption from the alimentary tract and increasing its urination, which include insufficient vitamin D intake, excessive iron, zinc and magnesium intake, presence of phitynians or oxalates or excess of fat acids in the consumed meals, excessive consumption of alcohol, protein and caffeine, improper calcium-phosphor proportion in the diet or presence of the insoluble cellulose fractions [22]. It is very important to consume phitynians, oxalates or tannins, which are anti-nutritious substances, naturally occurring in food and which form, together with the bivalent ions, insoluble complex salts that affect bio-availability of other diet components. A negative impact on the calcium metabolism is observed when such stimulants as tobacco, alcohol or caffeine are used. Consumption of large amounts of caffeine coffee causes a temporary decrease in calcium excretion and it seems to be important mainly in elderly people, in whom proper intake of this element is difficult [23]. Cadmium included in tobacco decreases synthesis of the active vitamin D metabolite in kidneys, which adds to the bone demineralization and increases calcium excretion together with urine [24]. In turn, alcohol decreases bone mineral density due to the vitamin $D$ metabolism impairing, which results in the calcium metabolism disorder. Moreover, both smoking and excessive alcohol consumption show their direct toxic impact on osteoblasts [25].

An integral relationship between the bone metabolism and calcium management by the organism exists in the vitamin $\mathrm{D}$ activity mechanisms. This vitamin positively affects calcium absorption in the intestines and its reversible resorption in kidneys. Moreover, it significantly affects functioning of osteoblasts, increases muscle power and improves the movement coordination, which decreases a fall risk. The vitamin D demand is covered by its dermal synthesis due to sunbeams (ca. 80\%) and - to a less extent - thanks to the diet (ca. 20\%). The dermal vitamin D synthesis is guaranteed only by proper exposure to sunbeams, which means uncovering of minimum $15 \%$ of the skin surface for minimum 20 minutes per day, within the May-September period. One should not forget also that application of the protective creams with the SPF 8 or higher filters may restrain as much as $97.5 \%$ of the vitamin D production in the skin [8]. The vitamin D precursor is cholesterol, endogenously synthesized in the human organism, in amounts enough to cover its daily demand (this element may not be delivered in the diet) [26].

The vitamin D exists in small quantities in food, mainly in cod-liver oil, fat fish or hen's liver. The nutrition sources become important mainly in the winter season. The age-related, less efficient dermal vitamin D synthesis, within the peri-menopausal period results in the recommended daily supplementation of the 200400 IU dose. A larger dose (800-1000 IU) is recommended for the supplementation in the post-menopau- sal period due to the fact that in this life period women begin to suffer from chronic diseases, therefore they lead a stationary lifestyle and spend most of their days indoors, which prevents the dermal vitamin D synthesis [27]. Research of Nieves et al. on a group of the Caucasian post-menopausal women shows that the best effects in limitation of the osteoporosis or osteoporosisrelated fracture risk, are obtained by ensuring proper intake of these two food components - calcium and vitamin D [28]. Similar conclusions relating to the high therapeutic impact of the combined calcium and vitamin D supplementation on the osteoporosis prevention are shown by Tang et al. and Lips et al. [19, 29]. Pfeifer et al. proved additionally that the combined supplementation of the two discussed components positively affects not only the osseous system, but also the neuromuscular functions, which may positively affect the fall risk drop in elderly people [30].

Proper osseous metabolism is also significantly affected by proteins, magnesium, vitamin $\mathrm{K}, \mathrm{C}$ and $\mathrm{B}$ vitamins. In order to maintain proper osseous mineralization it seems to be best to provide optimum protein intake at a level of 0.9-1.0 per $1 \mathrm{~kg}$ of body mass, because both its deficit and excess may negatively affect the calcium absorption from the alimentary tract. Limitation of the calcium resorption is caused mainly by excessive consumption of the animal protein, and therefore it is recommended to substitute it in the diet with plant proteins $[23,31]$.

Considering the above mentioned negative results of protein over-consumption, it seems to be specially dangerous in the osteoporosis risk aspect to use a high protein diet (especially as the slimming diet) [23, 32]. The protein deficit in a diet results in a decrease in the soft tissue surrounding the hips, which consequently leads to a higher exposure of the deeper tissue layers to mechanical force impact in the case of falls or traumas. The scanty protein supply causes also a decrease in the bone mass, bone micro-architecture disorder or cortical bone thinning. Therefore, the protein deficit in peri-menopausal women may, within a short time, lead to development of advanced osteoporosis [33].

It is recommended for elderly people to consume every day 1.0-1.3 g of proteins per $1 \mathrm{~kg}$ of the body mass due to necessary compensation of the deficit resulting from a lower consumption of calories. Moreover, the research proves that an increase in the daily consumption up to 1.5-1.6 g per $1 \mathrm{~kg}$ of the body mass may add to improvement of the muscle power and bone health in elderly patients [15]. A significant magnesium deficit results in the structural disorder in the skeleton construction and presence of the $D_{3}$ vitamin resistance, which results in limitation of the calcium absorption. Such deficit occurs very rarely due to common presence of magnesium in food. The recommended daily magnesium intake in the diet should be $320 \mathrm{mg}[13,23]$. 
The important mineral component, taking part in the bone or teeth mineralization process, is phosphorus. The recommended phosphorus dose in the diet, for both sexes, is $700 \mathrm{mg}$. The phosphorus deficit rarely leads to the muscle or bone asthenia or osteomalacia, due to its common presence in food, while its excessive consumption (over $1 \mathrm{~g}$ a day) may, together with the calcium deficit, disturb the vitamin D synthesis. Moreover, the phosphorus excess in a diet fosters creation of insoluble calcium phosphate inside the urinary tract, and this limits calcium absorption and additionally stimulates production of parathormone that in turn stimulates bone resorption [23].

The indirect measure of calcium absorption ability is the diet's calcium-phosphorus ratio, which cannot be lower than $1: 1$. The phosphate excess in a diet limits calcium retaining in organism and its high consumption causes a risk of soft tissue calcification and bone porosity increase. The phosphorus excess may also negatively affect absorption of other mineral elements such as magnesium or zinc salts [13,23]. Sodium excess may also have a negative impact on the calcium metabolism, because consumption of $1 \mathrm{~g}$ of sodium causes excretion of $26 \mathrm{mg}$ calcium with the urine [14].

Vitamin K positively affects functions of one of the main osseous proteins - osteocalcin. The nutrition

Table III. Basic sources of nutrition components, relevant to osteoporosis diet-prevention (prepared by the authors on the basis of Jarosz [13] and Kwiatkowska [37])

\begin{tabular}{ll}
\hline Nutrition component & Sources \\
\hline calcium & $\begin{array}{l}\text { milk and its products, canned fish } \\
\text { consumed with fish bones, nuts }\end{array}$ \\
\hline vitamin D & sea fish, fish oil, meat, milk products \\
\hline magnesium & $\begin{array}{l}\text { cereal products, leguminous plant } \\
\text { seeds, nuts, cacao, plain chocolate, } \\
\text { rennet cheese, fish, potatoes, some } \\
\text { vegetables, hard potable water }\end{array}$ \\
\hline phosphor & $\begin{array}{l}\text { rennet cheese, buckwheat groats, } \\
\text { canned fish, smoked fish consumed } \\
\text { together with fish bones, fish, haslets, } \\
\text { meat, eggs }\end{array}$ \\
\hline sodium & $\begin{array}{l}\text { vegetables (savoy cabbage, spinach, } \\
\text { broccoli, Brussels sprouts, lettuce, } \\
\text { parsley leaves), some plant oils, nuts }\end{array}$ \\
\hline vitamin K & $\begin{array}{l}\text { vegetables (parsley leaves, red pa- } \\
\text { prika, cabbage), berry or citrus fruits }\end{array}$ \\
\hline cellulose - soluble & $\begin{array}{l}\text { leaf vegetables, wheat sprouts, yeasts, } \\
\text { avocado, soya, green peas, beans, } \\
\text { walnuts, peanuts, bananas, starchy } \\
\text { vegetables, flour, dairy products, poul- } \\
\text { try, fish, eggs }\end{array}$ \\
\hline full-grain bread \\
\hline phytomin C
\end{tabular}

standards recommend a daily vitamin $\mathrm{K}$ intake of $55 \mu \mathrm{g}$ in women or $65 \mu \mathrm{g}$ in men. Similarly as in the case of magnesium, the deficits occur rarely, due to the common presence of vitamin $\mathrm{K}$ in food and synthesis by microbes existing in the human alimentary tract [23]. In post-menopausal women, vitamin $\mathrm{K}$ is responsible for decreasing the osseous mass and increasing reverse calcium absorption in kidneys, which results in a decreased osteoporosis fracture risk [34]. The vitamin K deficit results in the bone mineralization process disorder [13].

Vitamin $C$ takes part in absorption of calcium and iron [13]. The vitamin C recommended daily intake should be $75 \mathrm{mg}$ for women or $90 \mathrm{mg}$ for men. There are scientific reports about a positive impact of the enlarged $C$ vitamin intake in a diet on the mineral bone density, when a proper calcium dose is maintained. A similar impact was observed for the $C$ vitamin supplementation [23]. The B vitamins deficit (including the folic acid) may lead to an increase in the homocysteine concentration, which may result in stimulation of osteoclasts or collagen cross-linking process disorder that correlates with the increased bone fragility [35]. An important factor relating to covering of the $\mathrm{B}_{6}$ vitamin demand is the protein consumption (optimal ratio should be $0.02 \mathrm{mg}$ of vitamin $B_{6}$ for $1 \mathrm{~g}$ of protein) [13]. A positive impact of the cellulose fractions on the calcium absorption from the alimentary tract is also observed, however its quantity in diet is usually too small for such effect to occur. The insoluble fractions, consumed in excessive quantities, increase calcium urination, and also make it mechanically difficult to assimilate magnesium, iron or zinc. Assimilability of mineral components may also be negatively affected by the ion-exchange properties, characteristic of selected insoluble cellulose fractions. Moreover, the excessive consumption of such fractions (especially xylogens) may cause a decreased use of mineral components by the durable calcium or iron ions. According to nutrition standards, elderly people should consume daily 25-30 g of cellulose $[13,14,23]$. The scientists are also interested in the impact of phytoestrogens on the osseous tissue metabolism in the vitamin D stimulation mechanism. These compounds may significantly affect the osteoporosis prevention because they have a similar impact as human estrogens, thanks to which they may prevent the bone tissue resorption [36, 37]. Moreover, isoflavones (flavonoids belonging to phytoestrogens) seem to be able to inhibit the impact of osteoclasts and to stimulate osteoblasts. Researches show that inclusion of soya products in the everyday menu positively impacts the bone tissue mass and density [38].

Sources of mineral salts, vitamins and compounds mentioned in the work are shown in Table III.

If it is impossible to meet the nutrition recommendations in the everyday diet, then it is recommended to supplement the diet with vitamins and mineral components. 
The supplementation necessity, especially in elderly people, must be each time confirmed by a doctor or dietician. Uncontrolled use of such products is connected with a high risk of their improper application (too high/low doses, taking of several preparations with the same ingredients, interaction with medicines or food components), which consequently may lead to negative health results [39]. Moreover, if no medical consultation was made, there is a risk of the diet supplementing while consuming products enriched with vitamins and minerals, which may result in exceeding of upper safe consumption limits. Table IV shows products enriched with selected nutrition components, available on Polish market.

In the osteoporosis nutrition prevention patients should be informed not only about the products, everyday consumption of which guarantee supply of vitamins and mineral components on the recommended level, but also about their preparation method. In order to main tain their high nutrition value, it is improper to use such initial food preparation methods as long-lasting soaking (e.g. vegetables before cooking) or unnecessary vegetable or fruit peeling, when those products may be carefully washed only. Also selection of the thermal food process ing technique is very important for maintaining biological values of the prepared meals. It is especially recommended to use steam boiling, stewing following the product fat-free frying or roasting in foil or heat-proof container or on a broach. Water boiling or use of the resulting stock for further meals must be avoided. It is also not recommended to fry products on fat, because during such thermal processing, harmful compounds (e.g. acrolein) may occur, and the obtained meals are indigestible [14].

The basis of osteoporosis diet-prevention is deemed, first of all, to be patient's education in order to make them respect a pro-health lifestyle and introduce changes to their nutrition behavior, which foster proper functioning of their osseous systems.

\section{Arrangement of nutrition education in osteoporosis}

The nutrition education in the osteoporosis prevention should be a continuous process because nutrition habits impact on proper development and functioning of the osseous system begins just after the birth. Within the first months and years of human life such education should be addressed to child parents and it seems to be most effective if the education is provided by a primary health care midwife and then by a pediatrician. The most important link in the pro-health education in elderly people is the primary health care physician, while in the perior post-menopausal women it is the gynecologist.

Each individual contact with the patient fosters pro-health education and enables adapting the education process to his (her) needs; the efficiency basis here is the subjective treatment of patients, establish- ing of partnership relations between the participants (doctor-patient) and following the two-way interpersonal communication conditions. Nutrition education in the doctor's practice is carried out mainly in the form of explanations (concise delivery of contents, definitions, phenomena causes) or advice (doctor's initiative), more rarely by guidance (patient's initiative) [40]. High efficiency of the pro-health education in osteoporosis requires an active cooperation between a $\mathrm{PHC}$ physician with other specialists. The significant and obvious role is played here by orthopedists, endocrinologists, rheumatologists and the above mentioned gynecologists for the menopausal women. In the fall prevention, this group should also include ophthalmologists, neurologists, cardiologists and laryngologists. Moreover, if the calcium or vitamin D supplementation is recommended, then the family doctor may expect support of such specialists as dieticians, allergists, nephrologists or cardiologists [41]. Thus, the osteoporosis female patient supervision requires a comprehensive approach, i.e. provision of health care services including all its stages and elements and also close cooperation between the medical (doctors, nurses, midwives) and nutrition (nutrition specialists/dieticians) sectors.

The nutrition education process in osteoporosis should be at least equally efficient in the nurse or midwife professional practice. Both the primary health care nurses and those rendering services as part of the longterm care may take an active nutrition education process using methods analogous to those used by a PHC physician and additionally stimulating forms, applied during home visits. Such forms include e.g. teaching how to interpret food labels or teaching how to prepare meals rich in nutrition components necessary for maintaining and strengthening the osseous system health. This education should be directed not only to the patient him/herself, but also to his (her) family and besides the proper nutrition elements it should also include education relating to fall prevention. In practice of PHC midwifes or nurses cooperating with the gynecologists, the possible nutrition education involves mainly didactic lessons (explanations, advice) [40, 41].

Also in the hospital care system (hospital, health resort) the nutrition education is provided by the health

Table IV. Products available on Polish market, enriched with selected nutrition components (prepared by the authors on the basis of Wolnicka and Rychlik [10])

\begin{tabular}{ll}
\hline Nutrition component & Enriched products \\
\hline \multirow{2}{*}{ calcium } & $\begin{array}{l}\text { fruit juices and drinks, puddings, } \\
\text { desserts, milk products, flour, bread, } \\
\text { pasta, breakfast cereal, soya products }\end{array}$ \\
\hline vitamin D & margarine, milk, milk products \\
\hline vitamin $B_{12}$ & $\begin{array}{l}\text { fruit juices and drinks, starch jellies, } \\
\text { milk products, pasta, breakfast cereal }\end{array}$ \\
\hline
\end{tabular}


care personnel during hospitalization (both due to osteoporosis fractures and all other disease entities that do not prevent active participation in the education process). Moreover, such education may be provided in the health promotion rooms, arranged at health care institutions, with an independent post of a nurse (e.g. health care specialist). A similar solution may be used also in the above open health care system. Currently, the health promotion consultancies are not a separate service financed by NFZ (National Health Fund), and therefore their provision may be difficult because of costs paid by the service provider. One cannot forget however that such activity may significantly improve the quality of such services, prevent illness recurrences and prolong the remission period, which in turn may be very important for the costs rationale [42].

The nutrition education in osteoporosis should be also provided in the form of preventive programs directed to high-risk groups. For peri- and post-menopausal women at the pre-retirement age, such actions, outside health care institutions, may also be taken at employment establishments, especially those employing women working in the sitting position (two risk factors: gender and low physical activity) [1]. Such programs should focus on intake of calcium and physical activity with an assumption that those elements should be treated as separate pro-health habits aimed to achieve the same goal. Scientific proofs show that interventions relating to individual habits are more efficient in change-causing than those aimed at several pro-health habits simultaneously. Therefore, the calcium intake or physical activity related actions within one preventive program should be carried separately, if possible (differences in topical blocks, time and realization forms and in the means or didactic methods) [43].

\section{Summary}

In the light of the current demographic changes, it is necessary to take preventive actions relating to osteoporosis and aimed at limitation of costs incurred by both the patient him/herself and the health care system. When planning the nutrition education for the osteoporosis female patients it should be assumed that the system and multi-week actions, oriented at step-by-step change of the improper nutrition behaviors of patients will give much better results than a single nutrition action in the form of leaflets, lecture or talk. The primary prevention directed to the specific risk group, which are peri- and post-menopausal women, should be realized in cooperation with medical profession representatives on different levels and it should focus on causing positive changes in patient's habits both as regards the nutrition method and physical activities. Provision of the prohealth education becomes particularly important given that osteoporosis is troublesome and incurable.

\section{Disclosure}

Authors report no conflicts of interest.

\section{References}

1. Tan AM, LaMontagne A, Sarmugam R, et al. A cluster-randomised, controlled trial to assess the impact of a workplace osteoporosis prevention intervention on the dietary and physical activity behaviors of working women: study protocol. BMC Public Health 2013; 13: 405.

2. Capture the fracture: A global campaign to break the fragility fracture cycle; www.iofbonehealth.org (access: 10.06.2013).

3. Relacja z Europejskiego Kongresu Osteoporozy i Osteoartrozy, Rzym 1720 kwiecień 2013; http://www.naukawpolsce.pap.pl (access: 10.06.2013).

4. Suzin J, Szubert M, Kowalczyk-Amico K. Osteoporoza - częsty problem kobiety po menopauzie. Prz Menopauz 2009; 13: 320-323.

5. Rabiej M, Dmoch-Gajzierska E. Profilaktyka osteoporozy. Położna Nauka Prakt 2011; 4: 12-15.

6. Kowalczyk-Nowakowska J, Dmoch-Gajzierska E. Zagrożenie osteoporozą w okresie okołomenopauzalnym. Położna Nauka Prakt 2009; 2: 12-17.

7. Cianciara D. Zarys współczesnej promocji zdrowia. Wydawnictwo Lekarskie PZWL, Warszawa 2010; 104-111.

8. North American Menopause Society. Management of osteoporosis in postmenopausal women: 2010 position statement of the North American Menopause Society. Menopause 2010; 17: 25-54.

9. Wieczorek-Chełmińska Z. Żywienie w osteoporozie. Wydawnictwo Lekarskie PZWL, Warszawa 2006; 22-61.

10. Wolnicka K, Rychlik E. Praktyczne wskazówki do realizacji zaleceń żywieniowych dla osób w starszym wieku. In: Jarosz M, Dzieniszewski J (eds.). Żywienie osób w wieku starszym. Porady dietetyków i lekarzy. Wydawnictwo Lekarskie PZWL, Warszawa 2008; 70-88.

11. Jarosz M, Rychlik E. Znaczenie wody u osób w wieku starszym i zalecenia dotyczące spożycia płynów. In: Jarosz M, Dzieniszewski J (eds.). Żywienie osób w wieku starszym. Porady dietetyków i lekarzy. Wydawnictwo Lekarskie PZWL, Warszawa 2008; 89-98.

12. Ciborowska H, Rudnicka A. Dietetyka. Żywienie zdrowego i chorego człowieka. Wydawnictwo Lekarskie PZWL, Warszawa 2010; 88-89.

13. Jarosz M (ed.). Normy żywienia dla populacji polskiej - nowelizacja. Instytut Żywności i Żywienia, Warszawa 2012.

14. Wieczorek-Chełmińska Z. Żywienie w osteoporozie. Wydawnictwo Lekarskie PZWL, Warszawa 2006; 22-61.

15. Peters BSE, Martini LA. Nutritional aspects of the prevention and treatment of osteoporosis. Arq Bras Endocrinol Metabol 2010; 54: 179-185.

16. Warensjo E, Byberg L, Melhus $\mathrm{H}$, et al. Dietary calcium intake and risk of fracture and osteoporosis: prospective longitudinal cohort study. $\mathrm{Br}$ Med J 2011; 13: 9.

17. Rouzi AA, Al-Sibiani SA, Al-Senani NS, et al. Independent predictors of all osteoporosis-related fractures among healthy Saudi postmenopausal women: The CEOR Study. Bone 2012; 50: 713-722.

18. Key TJ, Appleby PN, Spencer EA, et al. Calcium, diet and fracture risk: a prospective study of 1898 incident fractures among 34696 British women and men. Public Health Nutr 2007; 10: 1314-1320.

19. Tang BM, Eslick GD, Nowson C, et al. Use of calcium or calcium in combination with vitamin $D$ supplementation to prevent fractures and bone loss in people aged 50 years and older: a metaanalysis. Lancet 2007; 370: 657-666.

20. Bolland MJ, Grey A, Avenell A, et al. Calcium supplements with or without vitamin D and risk of cardiovascular events: reanalysis of the Women's Health Initiative limited access dataset and meta-analysis. BMJ 2011; 342: 1-9.

21. Cianferotti L, Brandi ML. Guidance for the diagnosis, prevention and therapy of osteoporosis in Italy. Clin Cases Miner Bone Metab 2012; 9: 170-178.

22. Brzozowska A. Składniki mineralne. In: Gawęcki J, Hryniewiecki L (eds.). Żywienie człowieka. Podstawy nauki o żywieniu. Wydawnictwo Naukowe PWN, Warszawa 1998. Za: Włodarek D. Znaczenie diety w zapobieganiu osteoporozie. Edokrynol Otyłość 2009; 5: 245-253.

23. Włodarek D. Znaczenie diety w zapobieganiu osteoporozie. Edokrynol Otyłość 2009; 5: 245-253.

24. Youness ER, Mohammed NA, Morsy FA. Cadmium impact and osteoporosis: mechanism of action. Toxicol Mech Methods 2012; 22: 560-567. 
25. Kanis JA, Johansson $\mathrm{H}$, Johnell $\mathrm{O}$, et al. Alcohol intake as a risk factor for fracture. Osteoporos Int 2005; 16: 737-742.

26. Jarosz M, Rychlik E. Przyczyny niedoboru makro- i mikroskładników u osób w wieku starszym. In: Jarosz M, Dzieniszewski J (eds.). Żywienie osób w wieku starszym. Porady dietetyków i lekarzy. Wydawnictwo Lekarskie PZWL, Warszawa 2008; 40-51.

27. Tkaczuk-Włach J, Sobstyl M, Jakiel G. Osteoporoza - zapobieganie i leczenie. Prz Menopauz 2010; 14: 283-287.

28. Nieves JW, Barrett-Connor E, Siris ES, et al. Calcium and vitamin D intake influence bone mass, but not short-term fracture risk, in Caucasian postmenopausal women from the National Osteoporosis Risk Assessment (NORA) study. Osteoporos Int 2008; 19: 673-679.

29. Lips PL, Bouillon R, van Schoor NM, et al. Reducing fracture risk with calcium and vitamin D. Clin Endocrinol (Oxf) 2010; 73: 277-285.

30. Pfeifer M, Begerow B, Minne HW, et al. Effects of a long-term vitamin D and calcium supplementation on falls and parameters of muscle function in community-dwelling older individuals. Osteoporos Int 2009; 20: 315-322.

31. Grześ A. Kwasica utajona - inne spojrzenie na osteoporozę. Przew Lek 2003; 6: 36-39.

32. Przysławski J, Nowak J. Assessing the intake of selected nutrients from food rations of menopausal women and andropausal men. I. Intake of energy and basic components. Pol J Food Nutr Sci 1999; 49: 125-134.

33. Zawada-Targoni S. Niedobór białka w diecie a zdrowe kości. Med Metab 2009; 13: 76-79.

34. Stránský M, Rysavá L. Nutrition as prevention and treatment of osteoporosis. Physiol Res 2009; 58: 7-11.
35. Kitchin B, Morgan SL. Not just calcium and vitamin D: other nutritional considerations in osteoporosis. Curr Rheumatol Rep 2007; 9: 85-92.

36. Al-Anazi AF, Qureshi VF, Javaid K, et al. Preventive effects of phytoestrogens against postmenopausal osteoporosis as compared to the available therapeutic choices: An overview. J Nat Sci Biol Med 2011; 2: 154-163.

37. Kwiatkowska E. Fitoestrogeny - rola prozdrowotna i zawartość w produktach. Post Fitoter 2009; 10: 107-112.

38. Cassidy A. Potential risk and benefits of phytoestrogen - rich diet. Int J Vitamin Nutr Res 2003; 73: 120-126.

39. Jarosz M, Stoś K, Respondek W, et al. Suplementy diety - korzyści i zagrożenia. Stand Med Pediatr 2009; 6: 304-308.

40. Woynarowska B. Edukacja zdrowotna. Wydawnictwo Lekarskie PWN, Warszawa 2010; 259-262.

41. Pluskiewicz W, Drozdzowska B, Fober E. Osteoporoza - profilaktyka od urodzenia do uzyskania szczytowej gęstości mineralnej kości. Lekarz 2009; 3: 55-58.

42. Sierpińska L. Organizacja ośrodka promocji zdrowia, pozyskiwanie funduszy na promocję zdrowia i tworzenie koalicji na rzecz zdrowia z pozycji zakładu opieki zdrowotnej promującego zdrowie. In: Charzyńska-Gula M (ed.). Zrozumieć promocję zdrowia. Przewodnik do zajęć. Wyd. Makmed, Lublin 2010; 141-142.

43. Sweet SN, Fortier MS. Improving physical activity and dietary behaviours with single or multiple health behaviour interventions? A synthesis of meta-analyses and reviews. Int J Environ Res Public Health 2010; 7: $1720-1743$. 